\title{
Особливості клініко-біохімічного та молекулярно-імунологічного статусу хворих на COVID-19 залежно від віку та супутньої патології
}

\author{
Василь Пикалюк ${ }^{1}$, Анна Ющук ${ }^{2}$ \\ ${ }^{1}$ Волинський національний університет імені Лесі Украйнки \\ ${ }^{2}$ КП «Волинська обласна інфекиійна лікарня»
}

Адреса для листування: pikaluk@ukr.net; annayushchuk2010@gmail.com https://orcid.org/0000-0001-8108-8216

Отримано: 10.08.21; прийнято до друку: 15.11.21; опубліковано: 30.12.21

Резюме. Поява (COVID-19) поставила перед фахівцями у сфері охорони здоров’я складні завдання, пов'язані зі швидкою діагностикою та клінічним веденням хворих із цією інфекцією. Хоч епідемія коронавірусної інфекції COVID-19 охопила весь світ, багато проблем щодо епідеміології, діагностики, клініки, лікування та профілактики цієї інфекції залишаються мало вивченими та неоднозначними.

У статті подано структурну характеристику (вікову, статеву, діагностичну) хворих на COVID-19, пролікованих на базі КП «Волинська обласна інфекційна лікарня» за 2020-2021 роки, охарактеризовано особливості гематологічних та біохімічних показників у хворих на COVID-19 різних вікових груп залежно від супутньої патології.

Виявлена кореляційна залежність між гематологічними, біохімічними, імунологічними та молекулярно-біологічними дослідженнями у хворих на COVID-19 різної статі та різних вікових категорій дозволить виробити принципи ранньої діагностики захворюваності, передбачити клінічний перебіг та створити персоніфікований підхід до лікування хворих з COVID-19. Результати дослідження дозволять підвищити ефективність діагностики та розробити критерії прогнозування щодо протікання захворювання, що надасть можливість забезпечити адекватну терапію, та збереження в подальшому здоров’я і життя хворих.

Ключові слова: коронавірус, COVID-19, лабораторна діагностика.

\section{Features of clinical-biochemical and molecular-immunological status of patients with COVID-19 depending on age and concomitant pathology}

\author{
Vasyl Pykalyuk ${ }^{1}$, Anna Yushchuk ${ }^{2}$ \\ ${ }^{1}$ Lesya Ukrainka Volyn National University \\ ${ }^{2} \mathrm{KP} «$ Volyn Regional Infectious Diseases Hospital»
}

Correspondence: pikaluk@ukr.net; annayushchuk2010@gmail.com.

Abstract. The advent (COVID-19) has posed difficult challenges for healthcare professionals in the rapid diagnosis and management of patients with this infection. Although the epidemic of COVID-19 infection has spread worldwide, many issues related to the epidemiology, diagnosis, clinic, treatment and prevention of this infection remain poorly understood and ambiguous.

The article presents the structural characteristics (age, sex, diagnostic) of patients with COVID-19, treated on the basis of KP «Volyn Regional Infectious Diseases Hospital» for 2020-2021, describes the features of hematological and biochemical parameters in patients with COVID-19 in different age groups depending on the concomitant pathology.

The revealed correlation between hematological, biochemical, immunological and molecular biological studies in patients with COVID-19 of different sexes and different age categories will allow to develop principles of early diagnosis of the disease, predict the clinical course and create a personalized approach to treatment of patients with COVID-19. The results of the study will increase the efficiency of diagnosis and develop criteria for predicting the course of the disease, which will provide adequate therapy and further health and life of patients.

Key words: viral infection, coronavirus, COVID-19, laboratory diagnostics. 


\section{ВСТУП}

Понад 100 років тому пандемія грипу, або так звана «іспанка», у 1918 році забрала щонайменше 50 мільйонів життів у всьому світі (за деякими даними 100 мільйонів). Тепер людство стикається 3 іншою пандемією - спалахом нового коронавірусу SARS-CoV-2, змушуючи нас жити 3 цим вірусом, можливо, протягом тривалого часу. 3 грудня 2019 року вченим та лікарям багато стало відомо про це захворювання під назвою COVID-19. Рівень смертності для COVID-19 оцінюється в діапазоні від 0,5\% до 3,5 \%, а клінічний прогноз захворювання становить: $40 \%$ - легка форма, $40 \%$ - помірна, $15 \%$ - важка, $5 \%$ - критична [1].

Коронавірус (COVID-19) вважається новим вірусом, що швидко поширився у всьому світі. У грудні 2019 року в провінції Хубей Китаю виявлений новий коронавірус під назвою Синдром важкого гострого респіраторного синдрому Коронавірус 2 (SARS-CoV-2) або (2019-nCoV) 3 невідомим походженням. Епідемічна хвороба, спричинена ГРВІ$\mathrm{CoV}-2$, називається коронавірусною хворобою-19 (COVID-19) [2; 3]. Вірусна інфекція поширилася на міжнародному рівні, і ВООЗ оголосила про надзвичайну ситуацію, пов'язану з міжнародним занепокоєнням у галузі охорони здоров'я. За даними ВОО3 від 24.10.2021 р. у всьому світі інфіковано 244226 978, серед них зареєстровано 4961726 смертельних випадків (2,0 \%), 221273492 випадків одужання (90,6%) і 17991760 (7,4%) хворіють зараз. В Україні, за даними Центру громадського здоров'я, станом на 24 жовтня, за весь час пандемії коронавірусної хвороби COVID-19 захворіло 2769405 осіб, одужало 2375776 осіб і летальних випадків 63872 .

Поширення вірусу SARS-CoV-2 породило грецький алфавіт штамів - систему іменування, яку використовує Всесвітня організація охорони здоров'я (ВОО3) для відстеження нових мутацій вірусу, що викликає COVID-19. Деякі з них оснастили вірус кращими способами зараження людей або ухилення від захисту, який забезпечують вакцини. На сьогодні вчені виявили багато різних штамів вірусу SARS-CoV-2, але найбільше занепокоєння викликають наступні:

- «Дикий» (L) - уперше зафіксовано в Китаї в грудні 2019 року;

- «Альфа» (В.1.1.7) - уперше виявили у Великій Британії в грудні 2020 року;

- «Бета» (В.1.351) - уперше зафіксовано в Південно-Африканській Республіці в грудні 2020 року;

- «Гама» (Р.1) - уперше знайдений у Бразилії в січні 2021 року;

- «Дельта» (В.1.617) - уперше виявлений в Індії у квітні 2021 року.

Мутація - це типове явище для всіх вірусів, а не тільки для SARS-CoV-2. Аналогічна ситуація спостерігається, наприклад, і з вірусом грипу.

Сьогодні вчені залишаються зосередженими на Delta - домінувальному штамі, який швидко поширюється у всьому світі, але відстежують і інші варіанти мутацій, аби передбачити, що може одного дня замінити Delta-штам.

Bapiaнт Delta, вперше виявлений в Індії, залишається найбільш тривожним. Цей штам вірусу вражає нещеплене населення у багатьох країнах $\mathrm{i}$ здатний заразити більшу частку вакцинованих людей, ніж його попередники.

BOO3 класифікує Delta як варіант, що викликає занепокоєння, тобто такий, що $є$ більш контагіозним, продемонстрував здатність викликати більш важкі захворювання або зменшувати користь від вакцин та лікування. Китайські дослідники виявили, що люди, інфіковані Delta, переносять на слизовій носа у 1260 разів більше вірусу, порівняно 3 оригінальним (первинним) варіантом коронавірусу.

I ще одна відмінність «на користь» Deltaштаму - первинний коронавірус персистував в організмі до семи днів перед появою симптомів. Натомість Delta може викликати симптоми на дватри дні раніше, що дає імунній системі менше часу для реагування та захисту.

Схоже, що Delta також мутує, і з'являються повідомлення про варіант Delta Plus - штам, який ухиляється від імунного захисту.

Bapiaнт Lambda привернув увагу як потенційна нова загроза. Але цей штам коронавірусу, вперше виявлений у Перу в грудні 2021 року, може відступати.

BOO3 класифікує Lambda-штам як варіант, що представляє інтерес. Lambda несе мутації, які, можливо, змінюють трансмісивність або викликають більш важке захворювання, але цей штам вірусу все ще розслідується. Лабораторні дослідження показують, що він має мутації, які є стійкими до вакциноіндукованих антитіл.

Поява (COVID-19) поставила перед фахівцями у сфері охорони здоров'я складні завдання, пов'язані зі швидкою діагностикою та клінічним веденням хворих із цією інфекцією. Хоч епідемія коронавірусної інфекції COVID-19 охопила весь світ, багато проблем щодо епідеміології, діагностики, клініки, лікування та профілактики цієї інфекції залишаються мало вивченими та неоднозначними. На сьогодні існує інформація, що цей вірус в основному передається повітряно-крапельним шляхом. Але $\epsilon$ дані про передання вірусу й іншими шляхами, зокрема контактним, фекально-оральним і навіть вертикальним шляхом. За даними літератури більшість інфікованих людей страждають легкими формами захворювання, зі схожими на грип симптомами [4]. При цьому для кожного третього інфікованого характерний важкий перебіг хвороби, а смертність складає 5-7 \%.

Метою нашого дослідження є вивчення циркуляції маркерів вірусу COVID-19 з характеристикою структури захворюваності, дослідження гематологічних, біохімічних та імунологічних показників і їх особливостей у взаємозв'язку з віком, статтю та супутньою патологією.

Завдання дослідження:

- визначити особливості циркуляції маркерів (антигену та антитіл) у хворих на COVID-19; 
- визначити структурний розподіл пацієнтів за статтю, віком, супутньою патологією;

- вивчити молекулярно-біологічні, імунологічні, гематологічні та біохімічні показники у хворих на COVID-19 залежно від віку, статі та супутньої патології;

- встановити взаємозв'язок між молекулярно-біологічними, імунологічними, гематологічними та біохімічними показниками у хворих на COVID19 залежно від віку та супутньої патології;

- розробити критерії ранньої діагностики важкості протікання та прогнозу виходу при інфекції COVID-19.

\section{МАТЕРІАЛИ ТА МЕТОДИ ДОСЛІДЖЕНЬ}

В процесі дослідження використано такі методи:

1. Імунологічні методи:

- метод імуноферментного аналізу (визначення імуноглобулінів А,M,G);

- метод імунохроматографії (визначення Антигена до COVID-19).

2. Молекулярно-біологічні дослідження:

- ПЛР реакція в режимі реального часу.

3. Гематологічні дослідження:

- загальний аналіз крові (метод кондуктометpii);

- мікроскопія клітин крові (цитологічний метод).

4. Біохімічні методи:

- визначення білкового обміну;

- визначення вуглеводного обміну;

- визначення ферментів;

- визначення лактату у цільній крові;

- визначення СРБ кількісного;

- визначення феритину;

- визначення газів крові (PO2,PCO2) та РН крові.

5. Гемостазіологічні методи:

- визначення фібріногену;

- визначення протромбінового індексу;

- визначення АЧТЧ;

- визначення МНВ;

- визначення Д-димер.

Обладнання, за допомогою якого проводили дослідження:

1. Біохімічний аналізатор автомат Cobaas 111.

2. Гематологічний аналізатор автомат Sysmex XNL 350 .

3. Аналізатор газів крові Siemens Rapid Point500.

4. Гемокоагулометр Bioksel 3003. Genius.

5. Молекулярна діагностика ПЛP ELITe In

Так, особам з підозрою на захворювання показаний комплекс клінічного обстеження для визначення ступеня тяжкості стану. Діагноз встановлюється на основі епідеміологічного анамнезу та результатів лабораторно-інструментальних методів досліджень.
Лабораторна діагностика є найбільш специфічним діагностичним критерієм у встановленні діагнозу. Ця діагностика за протоколами щодо обстеження на COVID-19 [5] включає: клінічний аналіз, біохімічний аналіз крові, дослідження С-реактивного білка (СРБ) в сироватці крові, дослідження гемостазу (включаючи Д-димер), дослідження кислотно-лужного стану крові, дослідження газів крові. Але в плані діагностики більш точною та надійною є специфічна діагностика вірусної інфекції. До такої діагностики, щодо вірусу COVID-19, належить виявлення його маркерів, тобто виявлення вірусу чи його антигенів, та визначення формування антитіл до цього вірусу. На сьогодні встановлення наявності вірусу антигенів або присутності вірусних білків (антигенів) проводиться за виявленням PHK COVID-19 методом ПЛР (на даний момент - найбільш точний метод). Лабораторне обстеження на PHK SARS-CoV-2 рекомендовано проводити всім особам з ознаками тяжкого гострого респіраторного синдрому та інших ГРВІ.

Для виявлення антитіл до COVID-19 на сьогодні розроблено визначення антитіл А, M, G методом імуноферментного аналізу. А також виявлення антигена методом імунохроматографії.

На сьогодні відомо, що чутливість тестів на антитіла тісно пов'язана 3 тим, коли проводиться тест. Тому, коли дослідники вивчили дані, отримані через 15-35 днів після появи перших симптомів, тести на антитіла точно виявили 90 \% людей 3 COVID-19.

24 червня 2020 року Cochrane libery було опубліковано висновки проаналізованих досліджень щодо діагностики коронавірусу: чутливість тестів на антитіла виявилась занадто низькою протягом першого тижня 3 моменту появи симптомів, щоб мати основну роль для діагностики COVID-19 [6].

При цьому аналіз загальних антитіл та Ig, G/Ig, М показали низьку чутливість протягом першого тижня 3 моменту появи симптомів (усі менше $30,1 \%$ ), зростаючи на другому тижні і досягаючи своїх найвищих значень на третьому тижні. Виявлення антитіл до SARS-CoV-2 має допоміжне значення для діагностики COVID-19 та основне значення для оцінки імунної відповіді на існуючу чи перенесену інфекційну хворобу.

Антитіла класу А (IgA) розпочинають формуватися і доступні для детекції приблизно з 2 дня від появи хвороби, досягають піку через 2 тижні та зберігаються тривалий час. Антитіла класу $\mathrm{M}(\mathrm{Ig} \mathrm{M})$ розпочинають виявлятися приблизно на 7 добу від початку хвороби, досягають піку через тиждень і можуть зберігатися впродовж 2-х місяців і більше. Приблизно з 3-го тижня або й раніше визначають антитіла класу G (Ig G) до SARS-CoV-2 [6].

Через те що не вивчені питання циркуляції маркерів вірусу, то не розроблені й критерії прогнозування, діагностики, а отже, й відповідного лікування. Це особливо стосується України, де виникнення епідемії може призвести до колапсу медичної галузі. 
Тому розробка критеріїв діагностики і прогнозування протікання хвороби, викликаної COVID-19, $є$ на сьогодні актуальною та надзвичайно важливою.

\section{РЕЗУЛЬТАТИ ДОСЛІДЖЕНЬ}

Нами проведено аналіз історій хворих на COVID-19 (штам В), пролікованих на базі КП «Во-

Статистичний аналіз історій захворювань хворих, пролікованих на базі КП «Волинська обласна інфекційна лікарня» за 2020 рік

\begin{tabular}{|c|c|c|c|c|}
\hline $\mathrm{Z}_{\text {Стать }}$ Вік & до 60 років & 60-70 років & $\begin{array}{c}\text { старші } \\
70 \text { років }\end{array}$ & Всього \\
\hline Чоловіки & $239(44,8 \%)$ & $180(33,8 \%)$ & $114(21,4 \%)$ & 533 \\
\hline Жінки & $297(40,6 \%)$ & $246(33,6 \%)$ & $187(25,6 \%)$ & 730 \\
\hline
\end{tabular}

Летальних випадків було 50 (серед жінок - 29, чоловіків - 21), що складало $3,7 \%$.

Також нами проведено статистичний аналіз історій захворювань хворих, пролікованих на базі КП «Волинська обласна інфекційна лікарня» за линська обласна інфекційна лікарня» за 2020 рік. Всього проліковано 1316 осіб, з них: чоловіків 533 (40,5\%), жінок - 730 (55,4 \%), дітей - 53 (4,02\%), 3 них 30 - дівчат та 23 - хлопці. Також проведено аналіз даних за наступними віковими категоріями та статтю (табл. 1).

Статистичний аналіз історій захворювань хворих, пролікованих на базі

КП «Волинська обласна інфекційна лікарня» за 2021 рік (за 8 місяців)

\begin{tabular}{|c|c|c|c|c|}
\hline 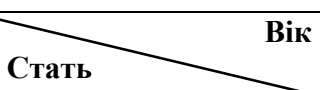 & до 60 років & 60-70 років & $\begin{array}{c}\text { старші } \\
70 \text { років }\end{array}$ & Всього \\
\hline Чоловіки & $240(51 \%)$ & $117(24,8 \%)$ & $113(24,0 \%)$ & 470 \\
\hline Жінки & $323(42,2 \%)$ & $238(31,1 \%)$ & $204(26,6 \%)$ & 765 \\
\hline
\end{tabular}

Летальних випадків 54, що складало 4,2 \% (серед жінок - 30, чоловіків - 24).

Ще одним кроком у дослідженні стало опрацювання групи хворих на COVID-19 (174 особи), які було розподілено за такими критеріями: хворі
2021 рік (8 місяців) (табл. 2). Всього проліковано 1276 осіб, з них чоловіків - 472 (36,9\%), жінок 763 (59,7 \%), дітей - 41 (3,2 \%) (дівчат - 22, хлопців - 19). Проведено аналіз даних за наступними віковими категоріями та статтю (табл. 2).

Табличя 2

Структура хворих на COVID-19 за віком та статтю

\begin{tabular}{|c|c|c|c|c|c|c|c|c|}
\hline \multirow{2}{*}{ Вік } & \multicolumn{2}{|c|}{$\begin{array}{c}\text { Хворі на COVID-19 } \\
\text { без супутньої патології } \\
\text { n=19 } \\
\end{array}$} & \multicolumn{2}{|c|}{$\begin{array}{c}\text { Xворі на COVID-19 } \\
\text { з супутньою патологією } \\
\text { n=75 } \\
\end{array}$} & \multicolumn{2}{|c|}{$\begin{array}{c}\text { Хворі на COVID-19 з } \\
\text { летальними випад- } \\
\text { ками n=47 } \\
\end{array}$} & \multicolumn{2}{|c|}{$\begin{array}{c}\text { Контрольна група } \\
\text { хворих із пневмонісю } \\
\text { без COVID-19 n=33 } \\
\end{array}$} \\
\hline & ч & ж & ч & ж & $\mathrm{Y}$ & ж & ч & ж \\
\hline \multirow[t]{2}{*}{ Зрілий } & \multicolumn{4}{|c|}{$\mathrm{n}=18 ;$ ж-10,ч- 8} & \multicolumn{2}{|c|}{$n=4$} & \multicolumn{2}{|c|}{$\mathrm{n}=15$} \\
\hline & 4 & 5 & 4 & 5 & 4 & 0 & 8 & 7 \\
\hline \multirow[t]{2}{*}{ Літній } & \multicolumn{4}{|c|}{$\mathrm{n}=55 ;$ ж-34, ч- 16} & \multicolumn{2}{|c|}{$\mathrm{n}=25$} & \multicolumn{2}{|c|}{$\mathrm{n}=16$} \\
\hline & 5 & 5 & 11 & 34 & 13 & 12 & 11 & 5 \\
\hline \multirow[t]{2}{*}{ Старечий } & & & \multicolumn{2}{|c|}{$\mathrm{n}=21 ; \%-14, \mathrm{ч}-7$} & \multicolumn{2}{|c|}{$\mathrm{n}=18$} & \multicolumn{2}{|c|}{$\mathrm{n}=2$} \\
\hline & 0 & 0 & 7 & 14 & 9 & 8 & 2 & 0 \\
\hline
\end{tabular}

Аналіз результатів дослідження засвідчує, що більшість хворих - це люди літнього віку. Летальні випадки складають 4,2 \%, а одужує 95,8 \%. Жінки $(59,1 \%)$ хворіють частіше, ніж чоловіки $(40,8 \%)-$ на $18,3 \%$.

Також групу обстежених хворих на COVID-19 було структуровано залежно від супутньої патології (рис. 1).

Основна маса хворих на COVID-19 із супутньою патологією мала гіпертонічну хворобу (62,3 \%); наступна група - цукровий діабет $(21,5 \%)$ та ішемічну хворобу серця (10,7\%);відсутність патології засвідчено у 5,4 \% хворих. без супутньої патології, з супутньою патологією та хворі з летальними випадками (табл. 3). Контрольна група (хворі з пневмонією без COVID-19) становить 33 особи.

Таблиия 3 


\section{Обстеження хворих на Covid-19 по супутнім захворюваннях}

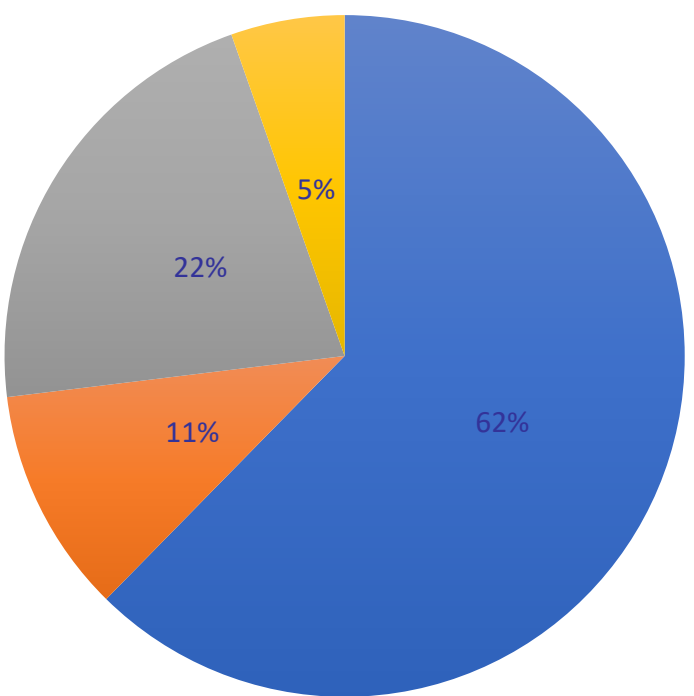

шіпертонічна хвороба Ішемічна хвороба Ц Цукровий діабет Відсутня

Рис. 1. Структура хворих на COVID-19 за їхньою супутньою патологією

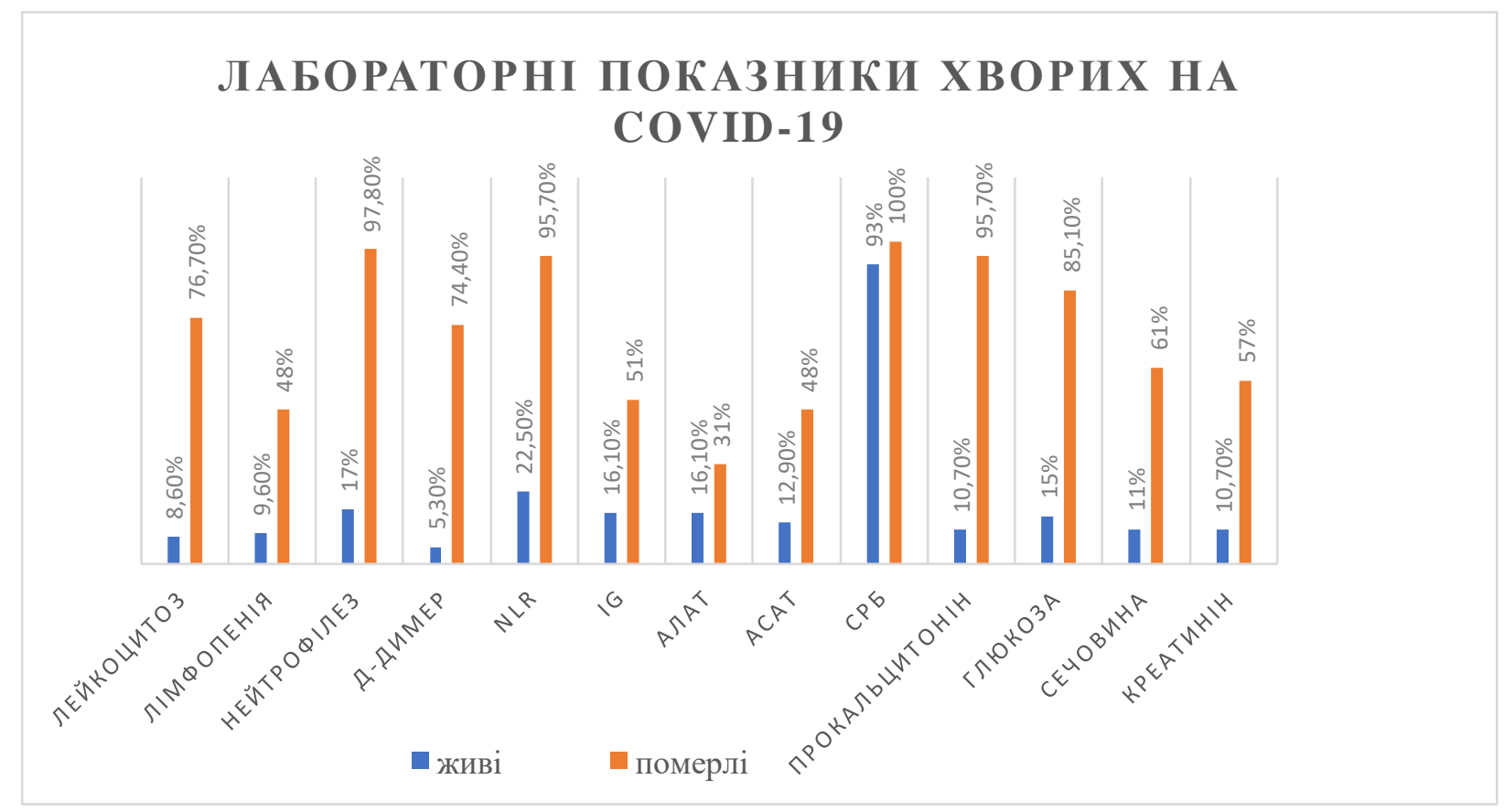

Рис. 2. Лабораторні показники хворих на COVID-19 (у групах:живі та померлі)

Результати гематологічних та біохімічних досліджень у групі померлих превалюють в 5-7 разів над показниками групи живих, окрім СРБ, який має тенденцію до збільшення в 90-100 \% випадках у двох групах та є статистично не достовірним.
Алгоритм діагностики щодо захворювання на COVID-19, чи підозру до нього, включає комплекс клінічного обстеження, а також загальної та специфічної лабораторної діагностики. Важливі лабораторні показники, які змінюються в пацієнтів із COVID-19, подані в табл. 4.

Таблиия 4

\section{Лабораторні показники, які змінюються у пацієнтів із COVID-19}

\begin{tabular}{|c|c|}
\hline \multicolumn{2}{|c|}{ І. Гематологічні параметри } \\
\hline $\mathbf{1}$ & $\mathbf{2}$ \\
\hline Лейкоцити (кількість) & Підвищення \\
\hline Нейтрофіли (кількість) & Підвищення \\
\hline
\end{tabular}


Закінчення таблиці 4

\begin{tabular}{|c|c|}
\hline 1 & 2 \\
\hline Лімфоцити (кількість) & Зниження \\
\hline Еозинофіли (кількість) & Зниження \\
\hline Тромбоцити (кількість) & Зниження \\
\hline \multicolumn{2}{|c|}{ II. Біохімічні параметри } \\
\hline Альбумін & Зниження \\
\hline Аланінамінотрансфераза & Підвищення \\
\hline Аспартатамінотрансфераза & Підвищення \\
\hline Загальний білірубін & Підвищення \\
\hline Сечовина & Підвищення \\
\hline Креатинін & Підвищення \\
\hline Креатинкіназа & Підвищення \\
\hline Лактатдегідрогеназа & Підвищення \\
\hline Міоглобін & Підвищення \\
\hline Серцевий тропонін & Підвищення \\
\hline Гамаглутамілдегідрогеназа & Підвищення \\
\hline \multicolumn{2}{|c|}{ III. Параметри гемостазу } \\
\hline Д-димер & Підвищення \\
\hline Протромбіновий час & Підвищення \\
\hline \multicolumn{2}{|c|}{ IV. Маркери запалення } \\
\hline С-реактивний протеін & Підвищення \\
\hline Ферритин & Підвищення \\
\hline Прокальцитонін & Підвищення \\
\hline Інтерлекін 2 & Підвищення \\
\hline Інтерлекін 6 & Підвищення \\
\hline Інтерлекін 8 & Підвищення \\
\hline Інтерлекін 10 & Підвищення \\
\hline
\end{tabular}

\section{ВИСНОВКИ}

У процесі дослідження встановлено структурну характеристику (вікову, статеву, діагностичну) хворих на COVID-19, пролікованих на базі КП «Волинська обласна інфекційна лікарня» за 20202021 роки, особливості гематологічних та біохімічних показників у хворих на COVID-19 різних вікових груп залежно від супутньої патології.

Отже, більшість хворих - це люди літнього віку з різними супутніми патологіями, а саме: гіпертонічна хвороба (62,3\%), цукровий діабет $(21,5 \%)$, ішемічна хвороба серця $(10,7 \%)$; не виявлено патології у 5,4 \% хворих.

Отримані результати дозволять підвищити ефективність діагностики та розробити критерії прогнозування щодо протікання захворювання, що дасть змогу забезпечити адекватну терапію, та збереження в подальшому здоров'я і життя хворих.

Виявлено також кореляційну залежність між гематологічними, біохімічними, імунологічними та молекулярно-біологічними дослідженнями у хворих на COVID-19 різної статі та різних вікових категорій. У гематологічних показниках група хворих 3 важким перебігом має високу лімфопенію та тромбоцитопенію. Результати гематологічних та біохімічних досліджень у групі померлих превалюють в 5-7 разів над показниками групи живих, окрім СРБ, який має тенденцію до збільшення в 90100 \% випадках у двох групах та є статистично не достовірним. У групі померлих ПЛР-тест на COVID-19 був позитивний упродовж 2-3 тижнів.

Результати дослідження дозволять виробити принципи ранньої діагностики захворюваності, передбачити клінічний перебіг та створити пер- соніфікований підхід до лікування хворих із COVID-19. Отримані результати можуть бути використані в медицині (інфектології та терапіі), біології (молекулярна біологія, імунологія, вірусологія) для лабораторної діагностики COVID-19.

Враховуючи невизначеність розвитку подій навколо коронавірусу, 3 великою ймовірністю.,що SARS-CoV-2 може стати супутником нашого життя на довгі роки, і людству потрібно пристосуватися до відповідних змін у повсякденному житті. У будь-якому випадку нова, смертельна для людства пандемія потребує величезної мобілізації ресурсів і доводить першорядне значення для сучасного світу.

\section{ЛІТЕРАТУРА}

1. Guan, WJ; Ni, ZY; Hu, Y; Liang, WH; Ou, CQ; He, JX; et al. Clinical Characteristics of Coronavirus Disease 2019 in China. The New England journal of medicine, 2020. URL: https://doi. org/10.1056/NEJMoa2002032.

2. Задорожна, В. І.; Винник, Н. П. Коронавірус 2019-nCOV: нові виклики охороні здоров'я та людству. Інфекційні хвороби. 2020, 1(99), с 5-15.

3. Никифоров, В. В. Новая коронавирусная инфекция (COVID19): клинико-эпидемиологические аспекты. Архив внутренней медичины. 2020, 10(2), с 87-93.

4. Huang, C; Wang, Y; Li, X; Ren, L; Zhao, J; Hu, Y; et al. Clinical features of patients infected with 2019 novel coronavirus in Wuhan, China. Lancet. 2020.

5. Chan, JF-W; Yuan, S; Kok, K-H; To, KK-W; Chu, H; Yang, J; et al. A familial cluster of pneumonia associated with the 2019 novel coronavirus indicating person-to-person transmission: a study of a family cluster. Lancet. 2020.

6. Backer, J. A.; Klinkenberg, D.; Wallinga, J. Incubation period of 2019 novel coronavirus (2019-nCoV) infections among travellers from Wuhan, China, 20-28 January. Euro Surveill, 2020, 25(5). URL: https://doi.org/10.2807/1560-7917.ES.2020.25.5.20 00062 